\title{
Przedsiębiorczy nauczyciel wczesnej edukacji - raport z badań
}

\section{Enterprising Early Childhood Education Teacher - Research Report}

Streszczenie: W dzisiejszych czasach, podczas zmian społecznych, które wymagają elastyczności, aby dostosować się do nowych warunków, przedsiębiorczość odgrywa ważną rolę. Ta umiejętność jest postrzegana jako jeden $\mathrm{z}$ najważniejszych celów współczesnej edukacji, w tym edukacji wczesnoszkolnej. Biorąc pod uwagę dynamiczną i często nieprzewidywalną pracę w zawodzie nauczyciela wczesnej edukacji, przedsiębiorczość, przede wszystkim w zakresie kreatywności i innowacyjności, jest konieczna. Ułatwia ona rozwiązywanie wielu problemów edukacyjnych, które często wymagają umiejętności radzenia sobie w różnych sytuacjach i kreowania nowych przedsięwzięć. Przedsiębiorcze podejście nauczyciela jest również ważne dla rozwoju przedsiębiorczości dziecka, gdyż pomaga uczniowi stawić czoła zmianom w otoczeniu i dostosować się do rozwijającej się rzeczywistości. Celem artykułu jest studium literaturowe z zakresu przedsiębiorczości edukacyjnej w odniesieniu do nauczyciela wczesnej edukacji i jego kompetencji w tym obszarze, określenie poziomu kompetencji przedsiębiorczych nauczycieli wczesnej edukacji w zakresie kreatywności i innowacyjności oraz dokonanie diagnozy w odniesieniu do stażu pracy na podstawie badań własnych.

\begin{abstract}
Nowadays, during social changes which demand flexibility to accommodate to new conditions, entrepreneurship plays an important role. This ability is seen as one of the most important goals in modern education, including early childhood education. Considering dynamic and very often unpredictable work as an early childhood education teacher, entrepreneurship, mainly in the field of creativity and innovations in this job is necessary. It simplifies solving many educational problems, which frequently demand ability to deal with various situations and create new ventures. Teacher's entrepreneurial attitude is also important for child's development of entrepreneurship, which helps pupils to face changes in environment and to adapt to developing reality. Communication abilities, necessary to develop creativity, are discussed in the article. The aim of the article is a literature study in the field of educational entrepreneurship in relation to an early childhood education teacher and his competence in this area, as well as to determine the level of entrepreneurial competence of early childhood education teachers in the field of creativity and innovation and to diagnose them according to seniority based on own research.
\end{abstract}

Słowa kluczowe: innowacyjność; kompetencje przedsiębiorcze; kreatywność; nauczyciel wczesnej edukacji; przedsiębiorczość

Keywords: creativity; early childhood education teacher; entrepreneurial competences; enterpreneurship; innovation 
Zaakceptowano: 23 marca 2020

Otrzymano: 23 March 2020

Received: 31 lipca 2020

Accepted: 31 July 2020

\section{Sugerowana cytacja/Suggested citation:}

Szkolak-Stępień, A. (2020). Przedsiębiorczy nauczyciel wczesnej edukacji - raport z badań. Przedsiębiorczość - Edukacja [Entrepreneurship-Education], 16(2), 38-47. doi: 10.24917/20833296.162.3

\section{Wstęp}

Współczesna edukacja ma za zadanie przygotować młode pokolenie do życia w ustawicznie zmieniającym się świecie, zatem nauczanie i wychowanie dzieci w młodszym wieku szkolnym to sprawdzian pomysłowości oraz talentu nauczycielskiego. Edukacja wymaga wrażliwego, mądrego, twórczego i krytycznego nauczyciela, potrafiącego wskazywać uczniowi różne możliwości wyboru indywidualnej drogi rozwoju i poszukiwania tożsamości. Bycie przedsiębiorczym stało się podstawowym wymaganiem dzisiejszego systemu oświaty, a zatem współczesny nauczyciel wczesnej edukacji powinien posiadać nowe kompetencje. Celem artykułu jest studium literaturowe z zakresu przedsiębiorczości edukacyjnej w odniesieniu do nauczyciela wczesnej edukacji i jego kompetencji w tym obszarze, określenie poziomu kompetencji przedsiębiorczych nauczycieli wczesnej edukacji w zakresie kreatywności i innowacyjności oraz dokonanie ich diagnozy w odniesieniu do stażu pracy na podstawie badań własnych.

\section{Edukacyjny przedsiębiorca - nauczyciel z pomysłem}

Pojęcie przedsiębiorczości związane jest głównie z biznesem, ale tak naprawdę dotyczy wszystkich sfer życia, również edukacji. E. Choinkowska podaje, że „przedsiębiorczość to realistyczne spojrzenie na potrzeby świata i umiejętność znalezienia w nim odpowiedniego miejsca dla siebie. To innowacyjność i kreatywność w myśleniu i działaniu. To odwaga w realizacji własnych pomysłów i marzeń” (Choinkowska, 2012: 127). Z kolei nauczyciel przedsiębiorczy to według autorki „nauczyciel twórczy, otwarty na nowości, który aktywnie szuka i wdraża nowe metody nauczania, by uczeń mógł rozwijać swoje zdolności. Jest autorytetem dla uczniów w wyznaczaniu i osiąganiu ambitnych celów" (Choinkowska, 2012: 133).

„Kluczową postacią przedsiębiorczości jest przedsiębiorca. W przypadku przedsiębiorczości edukacyjnej tym przedsiębiorcą jest nauczyciel” (Borgiasz, 2017: 189). Jakimi cechami powinien więc odznaczać się przedsiębiorczy nauczyciel? Jakie kompetencje powinien posiadać, by efektywnie pracować z dziećmi w młodszym wieku szkolnym?

W literaturze pojawia się znaczna liczba opracowań dotyczących kompetencji z zakresu przedsiębiorczości. Autorzy próbują dokonywać podziałów tychże kompetencji ze względu na różne aspekty, np. instruktażowe (Johannisson, 1993), instruktażowe poszerzone (Chandler, Hanks; 1994; Erikson, 2002), relacyjne (Man, Lau, Chan, 2002), kreatywno-predykcyjne (Lans i in., 2010) (za: Piróg, 2015). Jednak wielu autorów pojmuje kompetencje z zakresu przedsiębiorczości w aspekcie innowacyjności jako ustawicznego poszukiwania nietypowych rozwiązań, wprowadzania zmian, które są praktyczne 
i skuteczne, oraz kreatywności, która obejmuje robienie dobrze znanych rzeczy w nowy sposób, umiejętności radzenia sobie w rozmaitych sytuacjach życiowych. Przykładowo B. Bird podaje, że nauczyciel powinien inaugurować przedsięwzięcia, konstruktywnie rozstrzygać problemy, potrafić elastycznie dostosować się do aktualnej sytuacji (Bird, 1995). Dla P.F. Druckera nauczyciel przedsiębiorczy to osoba zdolna i gotowa do podejmowania nowatorskiego rozwiązywania zadań, wykorzystania szans i zagrożeń, dostosowania się do zmieniających się warunków (Drucker, 1992). J. Strojny uważa, że fundamentem osobowości przedsiębiorczej jest jej kreatywność i umiejętność rozwiązywania problemów (Strojny, 2007). Z kolei T. Brzozowski twierdzi, że przedsiębiorczość jest zdolnością do tego, aby ciągle się zmieniać, doskonalić i tworzyć lepsze możliwości do tego, by zaspokajać potrzeby i funkcjonować w społeczeństwie (Brzozowski, 2007) (za: Borgiasz, 2017).

Kompetencje przedsiębiorcze wyrażone kreatywnością nauczycieli przynoszą najlepsze efekty w rozwoju przedsiębiorczości u uczniów w młodszym wieku szkolnym. Twórczy nauczyciel będzie wyzwalał liczne talenty i możliwości uczniów, obudzi w nich ducha poszukiwacza i odkrywcy, pełnego twórczej dociekliwości optymisty.

Nauczyciel przedsiębiorczy pracujący z małym dzieckiem to z pewnością osoba z polotem, pomysłowa, ustawicznie rozwijająca się i uzupełniająca swoje kwalifikacje. Na co dzień staje on w obliczu nowych sytuacji wychowawczych i edukacyjnych. Jego praca wymaga stałego eksplorowania nowatorskich metod i technik nauczania. M. Podzielska twierdzi, że jednym z aspektów autorytetu nauczyciela jest jego atrakcyjność polegająca często na stosowaniu nietuzinkowych rozwiązań. Badaczka podkreśla, że nikt nie jest w stanie znosić przez dłuższy czas nudy, monotonii i rutyny. Co więcej, gdy nauczyciel jest przedsiębiorczy, to potrafi rozwijać kreatywność u swoich podopiecznych. Autorka pisze: „improwizacja wymaga kreatywności; dzięki niej Ty działasz szybko i skutecznie, a Twoi uczniowie uczą się rozwijania i wykorzystywania własnej pomysłowości" (Podzielska, 2009: 35).

Nauczyciel przedsiębiorczy wciąż się uczy. Jest zaangażowany w swoją pracę, jest też rzetelny, sumienny, dąży do realizacji postawionych sobie celów. Akceptuje swoich uczniów, rozumie ich potrzeby. Nauczyciel przedsiębiorczy to nauczyciel z pasją, nauczyciel z powołania. Uwielbia swoją pracę i oddaje się jej bez reszty. Stara się, aby każde zajęcia były ciekawe, mądre, wartościowe i pasjonujące. Ma cały czas na uwadze ucznia, który jest w centrum jego zainteresowań. Planując zajęcia, uwzględnia jego potrzeby, zainteresowania i możliwości. Nauczyciel optymista, nauczyciel kreatywny, powinien pobudzać uczniów do myślenia, do ciągłego samodoskonalenia się, do poszerzania swoich umiejętności, do realizowania pasji.

Również Ch. Day podkreśla, że nauczyciele powinni być przekonani, iż to, kim są oraz jak uczą, ma wpływ na życie ich podopiecznych w trakcie procesu nauczania, jak i wiele lat później. „Pasja jest kojarzona z entuzjazmem, troską, oddaniem i nadzieją. Gdy zapytasz uczniów o to, jakimi cechami powinien odznaczać się dobry nauczyciel, bardzo często wymieniają oni właśnie pasję i kreatywność” (Day, 2008: 28).

Zatem w pracy nauczyciela wczesnej edukacji zasadniczą rolę odgrywają kompetencje w zakresie przedsiębiorczości manifestujące się niekonwencjonalnością jego działań. 
Kompetencje przedsiębiorcze nauczycieli wczesnej edukacji w zakresie kreatywności i innowacyjności - wyniki badań własnych

Każdy nauczyciel rozpoczynający pracę w szkole musi uświadomić sobie, że kompetencje w zakresie przedsiębiorczości są mu niezbędne w codziennej pracy, podnoszą jej efektywność.

W związku z tym postanowiono przyjrzeć się bliżej wybranym kompetencjom przedsiębiorczym nauczycieli wczesnej edukacji - stanowiły one przedmiot badań własnych. Celem badań było określenie poziomu kompetencji przedsiębiorczych nauczycieli wczesnej edukacji w zakresie kreatywności i innowacyjności oraz dokonanie ich diagnozy w odniesieniu do stażu pracy. Badaniami objęto 112 nauczycieli klas I-III pracujących w miejskich szkołach podstawowych w województwie świętokrzyskim. Wykorzystano metodę sondażu diagnostycznego $\mathrm{z}$ techniką ankiety audytoryjnej przeprowadzonej w miejscu pracy respondentów, bez obecności ankietera, w marcu 2019 r. Posługiwano się kwestionariuszem samooceny dla nauczycieli, który zawierał 53 pytania dotyczące kompetencji pedagogicznych, z czego 4 dotyczyły stricte kompetencji przedsiębiorczych ${ }^{1}$. Pytania były zamknięte, ale z możliwością wyboru tylko jednej z trzech kategorii waloryzacyjnych: wysoka, średnia, niska. Główny problem badawczy brzmiał: Jaki jest poziom kompetencji przedsiębiorczych nauczycieli wczesnej edukacji z zakresu kreatywności i innowacyjności? W narzędziu badawczym zostały sformułowane następujące pytania badawcze:

1. Czy podejmuje Pani działania wyzwalające twórczą ciekawość u uczniów?

2. Czy kształtuje Pani u uczniów umiejętność radzenia sobie w różnych sytuacjach życiowych?

3. Czy doskonali Pani swój warsztat pracy, podejmuje próby jego modernizacji, wprowadza innowacje?

4. Czy tworzy Pani własne projekty edukacyjne, np. scenariusze zajęć zintegrowanych, artykuły, i publikuje je w czasopismach pedagogicznych lub w internetowych portalach edukacyjnych?

W pierwszej kolejności w ankiecie anonimowej pytano respondentów o to, czy podejmują działania wyzwalające u uczniów twórczą ciekawość (tabela 1).

Tabela 1. Samoocena dotycząca podejmowania działań wyzwalających twórczą ciekawość u uczniów w odniesieniu do stażu pracy nauczycieli wczesnej edukacji

\begin{tabular}{|c|c|c|c|c|c|c|c|c|c|c|}
\hline \multicolumn{11}{|c|}{ Czy podejmuje Pani działania wyzwalające twórczą ciekawość u uczniów? } \\
\hline \multirow{3}{*}{$\begin{array}{c}\text { Kategoria } \\
\text { samooceny }\end{array}$} & \multicolumn{8}{|c|}{ Staż pracy w latach } & \multirow{2}{*}{\multicolumn{2}{|c|}{ Ogółem }} \\
\hline & \multicolumn{2}{|c|}{$0-5$} & \multicolumn{2}{|c|}{$6-15$} & \multicolumn{2}{|c|}{$16-25$} & \multicolumn{2}{|c|}{ powyżej 25} & & \\
\hline & $\mathbf{n}$ & $\%$ & $\mathbf{n}$ & $\%$ & $\mathbf{n}$ & $\%$ & $\mathbf{n}$ & $\%$ & $\mathbf{n}$ & $\%$ \\
\hline Wysoka & 7 & 63 & 26 & 67 & 23 & 46 & 8 & 61 & 68 & 60 \\
\hline Średnia & 4 & 37 & 13 & 33 & 19 & 40 & 3 & 23 & 32 & 29 \\
\hline Niska & 0 & 0 & 0 & 0 & 7 & 14 & 2 & 16 & 12 & 11 \\
\hline Suma & 11 & 100 & 39 & 100 & 49 & 100 & 13 & 100 & 112 & 100 \\
\hline
\end{tabular}

Źródło: opracowanie własne

\footnotetext{
${ }^{1}$ Prezentowany sondaż stanowi wycinek szerzej zakrojonych badań dotyczących ustalenia poziomu kompetencji pedagogicznych nauczycieli wczesnej edukacji.
} 
Na podstawie analizy danych zawartych w tabeli 1 można stwierdzić, że większość nauczycieli (60\%) uważała, iż podejmuje działania wyzwalające twórczą ciekawość u uczniów (ocena wysoka). Około jedna trzecia badanych (29\%) oceniła swoją działalność w tym zakresie w stopniu średnim. Natomiast tylko $11 \%$ badanych przyznało, że nie dba o rozwój kreatywności u swoich uczniów. Biorąc pod uwagę staż pracy badanych nauczycieli, zdecydowanie najlepiej wypadli nauczyciele młodzi, którzy nie pracowali w zawodzie dłużej niż 5 lat, oraz nauczyciele, którzy pracowali w zawodzie od 6 do 15 lat. Wśród młodych nauczycieli wysoką ocenę w zakresie inicjowania nowych przedsięwzięć zadeklarowało 7 na 11 badanych (63\%), średnią - 4 na 11 badanych (37\%), natomiast żaden nauczyciel nie miał niskiej samooceny w tej kwestii. Podobnie w grupie nauczycieli o stażu pracy od 6 do 15 lat aż $67 \%$ z nich odznaczało się wysoką samoocenę w zakresie zachęcania uczniów do twórczości, a 33\% - średnią. Nie było za to osoby, która nie podejmowała takich działań. W zespole nauczycieli pracujących od 16 do 25 lat porównywalny procent respondentów wykazał wysoką (46\%) i średnią (40\%) samoocenę. Jednak były też osoby (14\%), które nie starały się o rozbudzenie u uczniów ducha odkrywcy. W gronie nauczycieli o stażu pracy powyżej 25 lat najwięcej osób wskazało na wysoki poziom starań o wyzwolenie u uczniów poczucia bycia „poszukiwaczem”- 8 z 13 osób (61\%). Niestety, 2 osoby (16\%) z najdłuższym stażem pracy nie deklarowały potrzeby wzbudzania twórczej ciekawości u dzieci.

Na współczesnej szkole spoczywa obowiązek podejmowania wciąż nowych przedsięwzięć i rozwijania u ucznia twórczej inwencji. Tylko nauczyciel przedsiębiorczy potrafi pokierować rozwojem ucznia, trafnie rozpoznać jego potencjał i twórcze możliwości intelektualne, uważnie podchodzić do wyników jego prac, zmotywować do długotrwałej współpracy i znajdować w niej obopólną radość. Wyniki badań własnych świadczą o tym, że nauczyciele wczesnej edukacji w większości znali i wykorzystywali metody rozwijające talenty i zainteresowania uczniów, ale istniała również niewielka grupa nauczycieli, która nie uznawała priorytetu stosowania niekonwencjonalnych metod pomagających odnaleźć dzieciom ścieżkę rozwoju osobistego, edukacyjnego i społecznego.

Kolejne pytanie w ankiecie dotyczyło kształtowania u uczniów umiejętności radzenia sobie w różnych sytuacjach życiowych (tabela 2).

Tabela 2. Samoocena stopnia kształtowania u uczniów umiejętności radzenia sobie w różnych sytuacjach życiowych w odniesieniu do stażu pracy nauczycieli wczesnej edukacji

\begin{tabular}{|c|c|c|c|c|c|c|c|c|c|c|}
\hline \multicolumn{11}{|c|}{ Czy kształtuje Pani u uczniów umiejętność radzenia sobie w różnych sytuacjach życiowych? } \\
\hline \multirow{3}{*}{$\begin{array}{c}\text { Kategoria } \\
\text { samooceny }\end{array}$} & \multicolumn{8}{|c|}{ Staż pracy w latach } & \multirow{2}{*}{\multicolumn{2}{|c|}{ Ogółem }} \\
\hline & \multicolumn{2}{|c|}{$0-5$} & \multicolumn{2}{|c|}{$6-15$} & \multicolumn{2}{|c|}{$16-25$} & \multicolumn{2}{|c|}{ powyżej 25} & & \\
\hline & $\mathbf{n}$ & $\%$ & n & $\%$ & n & $\%$ & $\mathbf{n}$ & $\%$ & $\mathbf{n}$ & $\%$ \\
\hline Wysoka & 3 & 27 & 20 & 51 & 17 & 35 & 3 & 23 & 46 & 41 \\
\hline Średnia & 7 & 64 & 11 & 28 & 28 & 57 & 9 & 69 & 54 & 48 \\
\hline Niska & 1 & 9 & 8 & 21 & 4 & 8 & 1 & 8 & 12 & 11 \\
\hline Suma & 11 & 100 & 39 & 100 & 49 & 100 & 13 & 100 & 112 & 100 \\
\hline
\end{tabular}

Źródło: opracowanie własne

Otrzymane wyniki (tabela 2) wskazują na to, iż porównywalny procent nauczycieli kształtował u uczniów umiejętność radzenia sobie w różnych sytuacjach życiowych 
wysoko - $41 \%$ - oraz średnio - 48\%, a tylko $11 \%$ przyznawało, że nie przykłada dużej wagi do takich działań. Wyniki takie były podobne we wszystkich grupach nauczycieli bez względu na kategorię stażu pracy. W najmłodszym zespole nauczycieli 3 osoby na 11 (27\%) zachęcały uczniów do poszukiwania sposobów radzenia sobie w nowych warunkach, 7 osób (64\%) robiło to stopniu średnim i tylko 1 osoba (9\%) - w stopniu niskim. W gronie respondentów ze stażem pracy od 6 do 15 lat sytuacja przedstawiała się następująco: 51\% badanych oceniało swoje działania umożliwiające uczniom kształtowanie umiejętności bycia elastycznym na wysokim poziomie, $28 \%$ - na poziomie średnim, a 21\% w ogóle nie deklarowało kształtowania umiejętności gotowości do zmiany u swoich uczniów. Spośród nauczycieli o stażu pracy od 16 do 25 lat prawie połowa (35\%) w wysokim stopniu oceniła swoje starania o rozwinięcie cechy bycia elastycznym, 28 osób - w stopniu średnim (57\%), a 4 - w niskim (8\%). Na podstawie samooceny nauczycieli, którzy pracują w szkole powyżej 25 lat, można stwierdzić, że $23 \%$ z nich szacuje poziom ww. umiejętności wysoko - 23\%, 69\% - średnio, a 8\% - nisko.

Materiał empiryczny wskazuje, iż nauczyciele wczesnej edukacji w średnim stopniu oceniają swoje próby kształtowania u uczniów umiejętności radzenia sobie w różnych sytuacjach życiowych.

Respondentów zapytano również o doskonalenie swojego warsztatu pracy, podejmowanie prób jego modernizacji i wprowadzanie innowacji. Wyniki zebrane w tabeli 3 dotyczą odpowiedzi udzielonych na omawiane pytanie z uwzględnieniem stażu pracy badanych nauczycieli wczesnej edukacji.

Tabela 3. Samoocena stopnia doskonalenia warsztatu pracy, podejmowania próby jego modernizacji, wprowadzania innowacji w odniesieniu do stażu pracy nauczycieli wczesnej edukacji

\begin{tabular}{|l|r|r|r|r|r|r|r|r|r|r|}
\hline \multicolumn{8}{|c|}{ Czy doskonali Pani swój warsztat pracy, podejmuje próby jego modernizacji, } \\
wprowadza innowacje?
\end{tabular}

Źródło: opracowanie własne

Jak wynika z tabeli 3, nauczyciele ocenili wysoko poziom doskonalenia własnego warsztatu pracy (89\%). Wszyscy nauczyciele pracujący nie dłużej niż 15 lat nie mieli żadnych problemów we wprowadzaniu innowacji do działań edukacyjnych. Nauczyciele bardziej doświadczeni zawodowo również podejmowali próby modernizacji warsztatu pracy. Wysoko oceniło się 44 nauczycieli (90\%), których staż pracy mieścił się w przedziale między 16 a 25 lat, oraz 9 nauczycieli (69\%) pracujących dłużej niż 25 lat. Jedynie $10 \%$ badanych średnio oceniło swoje twórcze działania w kontaktach z dziećmi - było to 5 nauczycieli z grupy ze stażem pracy mieszczącym się w przedziale od 16 do 25 lat oraz 4 nauczycieli (31\%) z grona osób o stażu pracy powyżej 25 lat. Nikt nie ocenił nisko swoich kreatywnych umiejętności w pracy dydaktyczno-wychowawczej. 
Podsumowując, należy podkreślić, że zdecydowana większość respondentów oceniła wysoko wkład własny w rozbudowywanie warsztatu pracy i wprowadzanie nowatorskich zmian. Tym sposobem wzbogacają oni praktykę nauczycielską o oryginalne rozwiązania, dzięki którym mają możliwość na osiąganie coraz lepszych efektów edukacyjnych.

Ostatnie pytanie dotyczyło tworzenia własnych projektów edukacyjnych i ich publikowania (tabela 4).

Tabela 4. Samoocena dotycząca tworzenia własnych projektów edukacyjnych i publikowania ich $\mathrm{w}$ czasopismach pedagogicznych i na internetowych portalach edukacyjnych $\mathrm{w}$ odniesieniu do stażu pracy nauczycieli wczesnej edukacji

\begin{tabular}{|c|c|c|c|c|c|c|c|c|c|c|}
\hline \multicolumn{11}{|c|}{$\begin{array}{l}\text { Czy tworzy Pani własne projekty edukacyjne, np. scenariusze zajęć zintegrowanych, artykuły } \\
\text { i publikuje je w czasopismach pedagogicznych, na internetowych portalach edukacyjnych? }\end{array}$} \\
\hline \multirow{3}{*}{$\begin{array}{l}\text { Kategoria } \\
\text { samooceny }\end{array}$} & \multicolumn{8}{|c|}{ Staż pracy w latach } & \multirow{2}{*}{\multicolumn{2}{|c|}{ Ogółem }} \\
\hline & \multicolumn{2}{|c|}{$0-5$} & \multicolumn{2}{|c|}{ 6-15 } & \multicolumn{2}{|c|}{$16-25$} & \multicolumn{2}{|c|}{ powyżej 25} & & \\
\hline & $\mathbf{n}$ & $\%$ & $\mathbf{n}$ & $\%$ & $\mathbf{n}$ & $\%$ & n & $\%$ & n & $\%$ \\
\hline Wysoka & 3 & 27 & 14 & 36 & 16 & 33 & 4 & 30 & 33 & 30 \\
\hline Średnia & 7 & 64 & 15 & 38 & 22 & 45 & 7 & 53 & 53 & 47 \\
\hline Niska & 1 & 9 & 10 & 26 & 11 & 22 & 2 & 17 & 26 & 23 \\
\hline Suma & 11 & 100 & 39 & 100 & 49 & 100 & 13 & 100 & 112 & 100 \\
\hline
\end{tabular}

Źródło: opracowanie własne

Analiza danych zawartych w tabeli 4 pozwala wnioskować, że największa liczba osób (47\%) swoje umiejętności tworzenia własnych projektów edukacyjnych szacowała na poziomie średnim. Zbliżony odsetek badanych określił te umiejętności wysoko - 30\% i nisko - $23 \%$. Nie było istotnych różnic w wynikach badań między grupami nauczycieli ze stażem pracy do 5 lat i od 6 do 15 lat, w których to około jedna trzecia badanych - odpowiednio $27 \%$ i $36 \%$ - wysoko oceniła swoje zaangażowanie w przygotowywanie scenariuszy, artykułów, ponad połowa - 64\% - i blisko połowa 38\% - średnio, a zdecydowana mniejszość - 9\% i 26\% - nie tworzy i nie zamieszcza tekstów w czasopismach pedagogicznych oraz w internetowych portalach edukacyjnych. Nieco gorzej wypadli nauczyciele o stażu pracy od 16 do 25 lat - 33\% z nich wysoko oceniło swoje umiejętności pisania projektów edukacyjnych, jednak aż $45 \%$ przyznało się do średniego stopnia zaangażowania w tworzenie scenariuszy zajęć itp. Natomiast 22\% respondentów nie zajmowało się opracowaniem i publikowaniem efektów swojej pracy z dziećmi. Ponad połowa nauczycieli z najdłuższym stażem pracy (53\%) w średnim stopniu oceniła swój wkład pracy w tworzenie projektów edukacyjnych. Wprawdzie 30\% (4 osoby) uważało, że kreuje nowe pomysły dydaktyczno-wychowawcze w wysokim stopniu, lecz 17\% (2 osoby) ujawniło, że nie przywiązuje wagi do projektowania nowatorskich strategii edukacyjnych.

Na podstawie badań można zatem stwierdzić, że nauczyciele wczesnej edukacji zarówno korzystają z już opracowanych i niejednokrotnie sprawdzonych przez kolegów koncepcji, jak i próbują tworzyć własne projekty, jednocześnie ponosząc za nie pełną moralną i profesjonalną odpowiedzialność, a także umieszczają swoje pomysły w internetowych portalach edukacyjnych czy publikują je w czasopismach pedagogicznych.

W uzyskanych wynikach występuje pewna sprzeczność. Z jednej strony respondenci przyznawali się do trudności w zakresie kreowania projektów edukacyjnych, z drugiej 
strony deklarowali wprowadzanie innowacji do procesu edukacyjnego. Wszystko wskazuje na to, że nauczyciele dostrzegają problemy w tworzeniu własnego warsztatu pracy, ale jednocześnie stale go modernizują.

\section{Podsumowanie}

Przedstawione wyniki badań wskazują na dwie zarysowujące się tendencje. Z odpowiedzi na pytania dotyczące przedsiębiorczości rozumianej jako kreatywność i innowacyjność można wnioskować, że z jednej strony nauczycieli charakteryzuje działanie twórcze przejawiające się, m.in., doskonaleniem własnego warsztatu pracy, podejmowaniem próby jego modernizacji oraz starań wyzwalających twórczość u uczniów. Ale z drugiej strony odpowiedzi respondentów na pytania o konkretne działania pokazują, że przedsiębiorczość nauczycieli wczesnej edukacji nie plasuje się już na tak wysokim poziomie, bowiem kształtowanie u uczniów umiejętności radzenia sobie w różnych sytuacjach w ich samoocenie wypada w średnim stopniu. Nauczyciele również przyznają, że nie zawsze są gotowi do opracowania i publikowania własnych projektów edukacyjnych, np. scenariuszy, programów nauczania czy artykułów.

Należy więc zastanowić się, gdzie leży przyczyna takiego stanu rzeczy. Czy powodem jest brak wrodzonych zdolności i predyspozycji przedsiębiorczych u niektórych nauczycieli wczesnej edukacji? Czy można przypuszczać, że odpowiada za to ich słabe przygotowanie na etapie szkoły średniej do twórczego wykorzystywania zdobytej wiedzy w praktyce? A może stopień złożoności niektórych wiadomości i umiejętności z obszaru przedsiębiorczości przekracza możliwości nauczycieli wczesnej edukacji bez kierunkowego wykształcenia? Czy wina jednak leży po stronie niedostatecznego przygotowania nauczycieli wczesnej edukacji w czasie studiów pedagogicznych? Wynikają stąd praktyczne postulaty pod adresem programów kształcenia nauczycieli, które powinny być wzbogacone o kursy Z metodyki zajęć przedsiębiorczości na etapie edukacji wczesnoszkolnej. Mimo że zgodnie $z$ podstawą programową dla etapu edukacji wczesnoszkolnej (Rozporządzenie...) treści z zakresu przedsiębiorczości nie są realizowane na tym szczeblu kształcenia w postaci odrębnej edukacji, to stanowią one ważny czynnik pracy dydaktyczno-wychowawczej z uczniami w młodszym wieku szkolnym (por. Rachwał i in., 2018).

Z ogólnego zestawienia samooceny nauczycieli wczesnej edukacji dotyczących ich przedsiębiorczości w zakresie kreatywności i innowacyjności wynika, że są one rozwinięte na średnim poziomie. Niemniej jednak tę część badań można podsumować optymistycznym stwierdzeniem, że badani nauczyciele potrafią spojrzeć krytycznie na własną pracę. Gwarantuje to uświadomienie sobie konieczności ciągłego rozwoju, potrzeby ciągłego uzupełniania swojej wiedzy oraz inicjowania operacji przedsiębiorczych u uczniów.

\section{Literatura}

References

Bird, B. (1995). Towards a theory of entrepreneurial competency. W: J.A. Katz, R.H. Brockhaus (red.), Advances in entrepreneurship, firm emergence and growth. Greenwich, CT: JAI Press, 51-72.

Borgiasz, M. (2017). Kompetencje przedsiębiorcze - ich rola i znaczenie w pracy współczesnego nauczyciela. Szkoła - Zawód - Praca, 14, 185-201. 
Brzozowski, T. (2007). Przedsiębiorczość - pojęcie polisemiczne czy niewłaściwe rozumiane. Próba systematyzacji. Przedsiębiorczość - Edukacja [Entrepreneurship - Education], 3, 196-203.

Chandler, G., Hanks, S. (1994). Founder Competence, the Environment, and Venture Performance. Entrepreneurship Theory \& Practice, 18(3), 77-89.

Choinkowska, E. (2012). Budowanie postaw przedsiębiorczych w pracy pedagogicznej przez oddziaływanie psychologiczne. Przedsiębiorczość - Edukacja [Entrepreneurship - Education], 8, 127-136.

Day, Ch. (2008). Nauczyciel z pasją. Jak zachować entuzjazm i zaangażowanie w pracy. Gdańsk: GWP.

Drucker, P.F. (1992). Innowacja i przedsiębiorczość. Praktyka i zasady. Warszawa: PWE.

Erikson, T. (2002). Entrepreneurial capital: the emerging venture's most important asset and competitive advantage. Journal of Business Venturing, 17, 275-290. doi: 10.1016/S0883-9026(00)00062-8

Johannisson, B. (1993). Entrepreneurial Competence and Learning Strategies. W: R. Larsson, L. Bengtsson, K. Eneroth, A. Malm (red.), Research in Strategic Change. Lund: Lund University Press, 77-99.

Lans, T., Biemans, H., Mulder, M., Verstegen, J. (2010). Self-awareness of mastery and improvability of entrepreneurial competence in small businesses in the agrifood sector. Human Resource Development Quarterly, 21(2), 147-168. doi: 10.1002/hrdq.20041

Man, T., Lau, T., Chan, K.F. (2002). The competitiveness of small and medium enterprises. A conceptualization with focus on entrepreneurial competencies. Journal of Business Venturing, 17(2), 123-142.

Piróg, D. (2015). Kompetencje z zakresu przedsiębiorczości: rozważania teoretyczne i ich ilustracje w obszarze szkolnictwa wyższego. Przedsiębiorczość - Edukacja, 11, 364-376. doi: 10.24917/2764

Rozporzadzenie Ministra Edukacji Narodowej z dnia 14 lutego 2017 w sprawie podstawy programowej wychowania przedszkolnego oraz podstawy programowej kształcenia ogólnego dla szkoły podstawowej, $w$ tym dla uczniów $z$ niepetnosprawnością intelektualna $w$ stopniu umiarkowanym lub znacznym, kształcenia ogólnego dla branżowej szkoły I stopnia, kształcenia ogólnego dla szkoły specjalnej przysposabiajacej do pracy oraz kształcenia ogólnego dla szkoły policealnej. Załąznik nr 2. Dz.U. 2017, poz. 356

Podzielska, M. (2009). Nauczyciel - lider - jak budować autorytet?. Warszawa: WSiP.

Rachwał, T., Kilar, W., Kawecki, Z., Wróbel, P. (2018). Edukacja w zakresie przedsiębiorczości w wychowaniu przedszkolnym, szkole podstawowej i szkołach średnich w świetle nowej podstawy programowej. Przedsiębiorczość - Edukacja [Entrepreneurship - Education], 14, 389-424. doi: $10.24917 / 20833296.14 .28$

Strojny, J. (2007). Kształtowanie postawy przedsiębiorczej - procesy socjalizacji i autokreacji. W: P. Wachowiak, M. Dąbrowski, B. Majewski (red.), Kształtowanie postaw przedsiębiorczych a edukacja ekonomiczna. Warszawa: FPiAKE.

Anna Szkolak-Stępień, dr, Uniwersytet Pedagogiczny im. Komisji Edukacji Narodowej w Krakowie, Instytut Pedagogiki Przedszkolnej i Szkolnej, Katedra Pedagogiki Wczesnoszkolnej. Doktor nauk humanistycznych w dziedzinie pedagogiki, tytuł przyznany przez Instytut Badań Edukacyjnych w Warszawie. Przedmiotem jej zainteresowań naukowych są zagadnienia z pedagogiki przedszkolnej i wczesnoszkolnej, pedeutologii, metodologii badań jakościowych. Obszar badań stanowią kompetencje profesjonalne nauczycieli wczesnej edukacji. Autorka zwraca szczególną uwagę na kwestie mistrzostwa pedagogicznego nauczycieli wczesnej edukacji.

Anna Szkolak-Stępień, PhD, Pedagogical University of Krakow, Institute od Preschool and School Pedagogy, Department of Preschool Education. PhD in Humanities in the field of pedagogy, the title awarded by the Educational Research Institute in Warsaw, Poland. Her research interests are issues of preschool and elementary education, pedeutology, methodology of qualitative research. The study area is the professional competence of early childhood education teacher. The author pays particular attention to the issues of the pedagogical mastery of an early childhood education teacher.

ORCID: https://orcid.org/0000-0001-5957-5616 
Adres/Address:

Uniwersytet Pedagogiczny im. Komisji Edukacji Narodowej w Krakowie Instytut Pedagogiki Przedszkolnej i Szkolnej

Katedra Pedagogiki Wczesnoszkolnej

ul. Ingardena 4, p. 311

30-060 Kraków, Poland

e-mail: anna.szkolak-stepien@up.krakow.pl 